\title{
Praktik Gadai Pohulo'o di Gorontalo dalam Perspektif Hukum Islam
}

\author{
Rulyjanto Podungge \\ Dosen Fakultas Syari'ah IAIN Gorontalo \\ Jl. Gelatik No. 1 Heledulaa Kota Gorontalo \\ ruly.podungge@gmail.com
}

\begin{tabular}{llll} 
Submit & $: 6$ Juli 2021 & Diterima & $: 2$ Nopember 2021 \\
Revisi & $: 27$ Oktober 2021 & Terbit & $: 1$ Desember 2021 \\
\hline
\end{tabular}

\begin{abstract}
Muslim communities believe that compliance with the law is not only in the field of worship, but also in the field of muamalah. Therefore, people want what they practice is legal and in accordance with Islamic teachings. One of the problems whose legal status continues to be questioned is the issue of pawning which is carried out under customary law. There have been many explanations regarding this problem by religious leaders, but their answers have not been able to satisfy the community. The answers available so far tend to conclude that the practice is not allowed, the law is haram. It is undeniable that the explanation of this in figh books is indeed the case, because the collateral in the pawn cannot be used by the pawnee, who in this case is a creditor. A creditor may not take advantage of the pledged goods for reasons of riba. However, the practice of pawning, which is carried out according to custom, has become a tradition in the community and is carried out with the pleasure of the pawnbroker and pawnee, and this tradition has become a means to get out of trouble to cover one's life. This article explains the problem of the pawn tradition in Muslim society through a sociological approach in addition to the usūliyah syar'iyah approach
\end{abstract}

Keywords: Pawn, Pawn Broker, Pawnee, Collateral, Rahn

Abstrak: Masyarakat muslim meyakini bahwa kepatuhan terhadap hukum bukan hanya pada bidang ibadah saja, tetapi juga menyangkut bidang muamalah. Olehnya masyarakat menginginkan agar apa yang mereka praktikkan adalah hal yang legal dan berkesesuain dengan ajaran Islam. Salah satu masalah yang terus dipertanyakan kedudukan hukumnya adalah masalah gadai yang dijalankan secara hukum adat. Telah banyak penjelasan menyangkut masalah ini oleh para tokoh agama, akan tetapi jawaban-jawaban mereka tidak mampu memuaskan masyarakat. Jawaban-jawaban yang tersedia selama ini cenderung memvonis bahwa praktik tersebut tidak dibolehkan, hukumnya haram. Tidak dipungkiri bahwa penjelasan hal ini dalam kitab-kitab fikih memanglah demikian, sebab barang jaminan dalam gadai tidak bisa dimanfaatkan oleh penerima gadai, yang dalam hal ini adalah seorang kreditur. Seorang kreditur tidak boleh memanfaatkan barang gadai karena alasan riba. Akan tetapi praktik gadai yang dijalankan dengan adat, telah menjadi sebuah tradisi di masyarakat dan dijalankan dengan rida dari pihak penggadai dan penerima gadai, dan tradisi ini telah menjadi sebuah sarana untuk keluar dari masalah untuk menutupi hajat hidup. Artikel ini menjelaskan masalah kedudukan hukum tradisi gadai pada masyarakat muslim melalui pendekatan sosiologis disamping pendekatan ușūliyah syar'iyah.

Kata Kunci: Gadai, Pemberi Gadai, Penerima Gadai, Barang Gadai, Rahn 


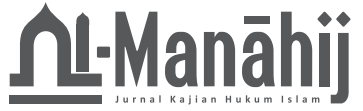

\section{Pendahuluan}

Harta dalam pandangan Islam menempati kedudukan yang sangat penting. Islam menempatkan harta sebagai salah satu dari lima kebutuhan pokok dalam kehidupan manusia yang harus dipelihara (al-ḍarūriyyāt al-khams). Al-p̣aruriyāt al-khams secara berurutan meliputi memelihara agama, memelihara jiwa, memelihara keturunan, memelihara akal dan memelihara harta. ${ }^{1}$ Meskipun harta menempati urutan kelima dari semua aspek al-ḍarüriyyāt al-khams ini, dia adalah sesuatu yang sangat urgen dalam pemeliharaan keempat aspek lainnya. Misalnya melaksanakan shalat sebagai bentuk perwujudan dalam pemeliharaan agama membutuhkan pakaian untuk menutup aurat.

Manusia tidak dibebaskan begitu saja mendapatkan harta serta memanfaatkannya dengan sekehendak hatinya, karena hal tersebut mendatangkan kekacauan dan kerusakan di tengah masyarakat. Oleh karena itu, Islam membuat aturan-aturan tertentu terhadap cara memperoleh kekayaan dan mengatur persoalan-persoalan kepemilikan. Kepemilikan harus diperoleh dengan cara halal. Demikian pula, mengembangkannya harus dengan cara yang dihalalkan.

Salah satu aktifitas ekonomi yang ada pada masyarakat dalam rangka memenuhi kebutuhan hidup adalah pinjam-meminjam uang. Aktifitas pinjam-meminjam uang sudah sangat lama dikenal masyarakat. Dalam praktiknya biasanya peminjaman uang akan disertai dengan jaminan benda. Mekanisme seperti ini dalam bahasa Indonesia disebut dengan gadai. Meminjam uang dengan cara menggadaikan barang pada masyarakat Indonesia telah menjadi tradisi, olehnya sampai dengan saat ini, gadai di berbagai daerah banyak dijalankan dengan tata cara adat.

Bagi masyarakat yang memiliki ekonomi menengah ke bawah, pinjaman dana dari lembaga keuangan resmi seperti bank dan pegadaian dirasakan sangat sulit, sehingga gadai dengan cara adat menjadi alternatif ringan yang bisa ditempuh. Peminjaman dana melalui lembaga resmi keuangan harus ditempuh dengan memenuhi syarat administrasi tertentu yang tidak mudah, atau bahkan tidak dapat dipenuhi oleh masyarakat, terutama bagi mereka yang berada pada golongan menengah ke bawah. Khusus masyarakat Gorontalo, tradisi gadai yang tunduk pada hukum adat juga marak terjadi terutama bagi masyarakat petani, dan menjadi solusi utama atas kebutuhan instant cash. Biasanya para petani memerlukan dana guna membiayai kebutuhan hidupnya atau keperluan lainnya, atau juga demi mendukung pembiayaan kegiatan-kegiatan usahanya. Tradisi gadai pada masyrakat Gorontalo disebut dengan pohulo'o. Benda jaminan hutang pada gadai pohulo'o adalah lahan sawah atau kebun. Lahan jaminan (marhūn) akan dikuasai sekaligus "dimanfaatkan" oleh pemegang jaminan (kreditur) ketika terjadi perjanjian pohulo'o. Di sinilah titik kritis nuansa riba pada tradisi ini, karena gadai dalam hukum Islam adalah akad tabarru' yang tidak membolehkan pemegang barang gadai (murtahin) mengambil manfaat darinya. Akan tetapi pada sisi yang lain tradisi ini telah banyak sekali membantu para petani dalam menanggulangi kebutuhan dana mereka.

Sebagai sebuah paraktik gadai yang lahir dari tradisi masyarakat dalam pranata ekonomi, pohulo'o harus ditilik eksistensinya. Tulisan ini berusaha memberikan penjelasan hukum Islam atas tradisi gadai, dengan studi kasus yang terjadi pada masyarakat Gorontalo, dengan metode penelitian kualitatif dan menggunakan pendekatan hukum sosiologis-progresif, disamping pendekatan ușūliyah syar'iyah. Lokasi penelitian mengambil tempat di tiga kecamatan Kabupaten Gorontalo.

\footnotetext{
Abū Ishāq al Syāṭibī, Al-Muwāafaqāt Fi Ușūl Al-Syari'ah (Beirut, Dār al-Ma'rifah, n.d.).
} 


\section{Gadai dalam Teori Fikih, Hukum Nasional dan Hukum Adat}

Definisi gadai menurut Subekti, adalah suatu hak kebendaan atas suatu benda yang bergerak kepunyaan orang lain, yang semata-mata diperjanjikan dengan menyerahkan benzit atas benda tersebut, dengan tujuan untuk mengambil pelunasan suatu utang dari pendapatan penjualan benda itu, lebih dahulu dari penagih-penagih lainnya. ${ }^{2}$

Dalam Hukum Islam, gadai diistilahkan dengan rahn atau al-rahn. Kata rahn terambil dari bahasa Arab yang bermakna al-subūt wa al-dawām, artinya tetap dan berkekalan. Ada yang menyatakan, kata al-rahn bermakna al-habs, artinya tertahan, seperti dalam firman Allah swt dalam QS Al-Muddasiir/47:



Tiap-tiap diri bertanggung jawab (tertahan) atas apa yang telah diperbuatnya.

Pada ayat tersebut, kata rahinah bermakna "tertahan". Pengertian kedua ini hampir sama dengan yang pertama, karena yang tertahan ini tetap ditempatnya. ${ }^{3}$

Dalam Islam, rahn merupakan akad tabarru' (akad saling tolong menolong) tanpa ada imbalan jasa. Al-Rahn hukumnya jāiz (boleh) menurut Al-Quran, Al-Sunnah dan Ijmā'. Allah mensyariatkan rahn (gadai) untuk kemaslahatan masyarakat, saling memberikan pertolongan di antara manusia, karena itu termasuk tolong-menolong dalam kebaikan dan takwa. Terdapat manfaat yang menjadi solusi dalam krisis, memperkecil permusuhan.

Adapun Rukun al-rahn menurut jumhur ulama ada empat, yaitu: al-Rahin, orang yang menyerahkan barang jaminan, al-Murtahin yaitu orang yang menerima barang jaminan, al-Marhūn, yaitu barang jaminan, al-Marhūn bih yaitu sejumlah dana berupa utang dan Sigat, yaitu pernyataan kehendak untuk berakad dari dua belah pihak yang berakad. Sementara itu rukun rahn menurut mazhab Hanafi adalah ijab dan kabul, sedangkan tiga lainnya merupakan syarat dari akad al-rahn. Di samping itu, menurut mereka untuk sempurna dan mengikatnya akad al-rahn ini maka diperlukan al-qabdu yaitu penyerahan barang oleh pemberi utang. ${ }^{4}$

Adapun syarat-syarat sahnya akad al-rahn, menurut jumhur ulama yaitu:

a. Al-Rahin dan Al-Murtahin, keduanya disyaratkan cakap bertindak hukum. Kecakapan bertindak hukum ditandai dengan balig dan berakal. Oleh karena itu, akad rahn tidak sah dilakukan oleh orang yang gila dan anak kecil yang belum mumayyiz.

b. Marhūn bih (utang), disyaratkan pertama, merupakan hak yang wajib dikembalikan kepada orang tempat berutang. Kedua, utang itu dapat dilunasi dengan marhūn (barang jaminan), dan ketiga, utang itu pasti dan jelas baik zat, sifat, maupun kadarnya.

Apabila agunan telah diterima oleh murtahin kemudian utang telah diterima oleh rahin, maka akad al-rahn bersifat mengikat bagi kedua belah pihak (dalam teori akad disebut luzūm). Syarat terahir yang merupakan kesempurnaan al-rahn, yakni penyerahan barang jaminan (qabḍ al-marhūn), artinya barang jaminan dikuasai secara hukum oleh murtahin. Syarat ini menjadi sangat penting sebagaimana dinyatakan oleh Allah swt. dalam surat Al-Baqarah yang ditunjukkan oleh lafal farihānun maqbūdoh. ${ }^{5}$

\footnotetext{
Subekti, Pokok-Pokok Hukum Perdata (Jakarta: Intermasa, 1999).

Sayyid Sābiq, Fiqh Al-Sunnah (Cairo: Dār al-Fath, 1997).

Wahbah Al-Zuhailī, Al-Figh Al-Islāmī Wa Adillatuh Juz V (Libanon: Dār al-Fikr, 1998).

‘Abd Al-Rahmān Al Jazīrī, Al-Fiqh ‘alā Mażāhib Al-'Arba'Ah (Mesir: Al-Maktabah al-Tijāriyah, 1998).
} 
Dalam akad rahn, murtahin tidak menerima suatu imbalan atau tambahan apapun dari rāhin. Begitu juga dengan barang gadai, ia tidak boleh diambil manfaatnya, baik oleh pemiliknya maupun oleh penerima gadai. Hal ini disebabkan status barang tersebut hanya sebagai jaminan utang dan sebagai amanat bagi penerimanya. Akad al-rahn dimaksudkan sebagai bentuk kepercayaan dan jaminan atas pemberian utang, bukan mencari untung darinya.

Dalam teori hukum nasional, gadai muncul karena akibat perikatan utang-piutang sebagai bentuk penanggungan pelunasan utang debitur terhadap piutang kreditur. Ia merupakan hak kebendaan dan timbul dari suatu perjanjian gadai. Perjanjian gadai inipun tidaklah berdiri sendiri melainkan merupakan perjanjian ikutan atau aksesoris dari perjanjian pokoknya berupa utang. Pemberi dan penerima gadai hanya dapat dilakukan oleh orang-orang yang cakap untuk melakukan perbuatan hukum, akan tetapi bagi pemberi gadai ada syarat lagi yaitu ia harus berhak mengasingkan benda yang digadaikan misalnya dengan menjual, menukar, menghibahkan dan lain-lainnya. ${ }^{6}$

Setelah kreditur menerima objek gadai, maka kreditur memiliki hak menahan benda yang digadaikan selama utang belum dilunasi pokok dan bunganya, serta biaya-biaya lainnya oleh debitur. Dalam melaksanakan hak gadai ketika menjual benda yang dijaminkan, pemegang gadai berhak untuk didahulukan menerima pembayaran piutangnya sebelum piutang-piutang lainnya, kecuali biaya-biaya lelang, biaya-biaya pemeliharaan agar barang itu tidak rusak atau musnah. ${ }^{7}$

Sebagai sebuah perbuatan hukum pemegang gadai memiliki kewajiban tanggung jawab atas hilangnya atau berkurangnya harga barang yang digadaikan, jika itu kelalaiannya. Pemegang gadai harus mengembalikan benda yang digadaikan bila mana hutang pokok, bunga dan biaya untuk memelihara benda yang digadaikan lunas dibayar oleh debitur. ${ }^{8}$ Hak kebendaan dari hak gadai bukanlah hak untuk menikmati suatu benda seperti eigendon, hak benzit, hak pakai dan sebagainya. Benda gadai memang harus diserahkan kepada kreditur tetapi tidak untuk dinikmati, melainkan untuk menjamin piutangnya dengan mengambil penggantinya dari benda tersebut guna mebayar piutangnya.

Terjadinya perjanjian gadai dimasyarakat juga dilakukan dengan hukum adat. Hukum adat memandang gadai, khususnya gadai tanah (lahan sawah atau kebun), sebagai hak yang bersifat memberikan kenikmatan. Pemegang/penerima gadai berhak untuk memungut hasil yang ditimbulkan oleh perjanjian gadai tersebut. Penebusan tanah sebagai objek gadai tergantung pada kemauan dan kemampuan yang menggadaikan. Inisiatif pelaksanaan gadai berasal dari keinginan pihak penggadai. Umumnya pelaksanaan gadai karena didorong oleh adanya tuntutan kebutuhan penggadai. Pemegang gadai hanya bersifat pasif menerima tawaran dari penggadai. Setelah bertemunya pihak penggadai dan pemegang gadai maka antara kedua pihak membuat kesepakatan atas pelaksanaan gadai.

Perihal waktu gadai, objek gadai, dan harga gadai, serta kesepakatan-kesepakatan lainnya antara pihak dituangkan dalam sebah perjanjian gadai tanah yang bersifat tertulis. Meskipun pada dasarnya hukum adat tidak mengenal tulisan sebagai alat bukti dalam suatu perbuatan hukum yang dibuat oleh warganya. Kadang-kadang perjanjian gadai agar mengikat kedua belah pihak maka dilaksanakan di

\footnotetext{
Hartono Hadisoeprapto, Pengantar Tata Hukum Indonesia (Yogyakarta: Liberty, 2000).

Ronald Saija, Buku Ajar Hukum Perdata (Yogyakarta: Deepublish, 2016).

8 J. Satrio, Hukum Jaminan Hak Jaminan Kebendaan (Bandung: PT. Citra Aditya, 2002).
} 
hadapan dan dengan bantuan penghulu rakyat atau kepala desa. ${ }^{9}$ Waktu gadai dalam hukum adat dicapai berdasarkan kesepakatan pemberi dan penerima gadai. Jika waktu gadai sudah jatuh tempo maka pemberi gadai berhak untuk menebus kembali tanah miliknya, tetapi jika pemberi gadai belum memiliki kemapuan untuk menebus tanahnya maka ada beberapa alternatif yang dapat dilakukan. Penerima gadai dapat menggadaikan kembali (mengalihkan gadai) tanah tersebut kepada pihak lain dengan ataupun tanpa persetujuan si pemilik tanah (pemberi gadai), hal ini dapat terjadi jika penerima gadai dalam keadaan sangat memerlukan uang, sedangkan pemberi gadai belum mampu untuk menggunakan hak tebusnya karena belum mempunyai uang misalnya. ${ }^{10}$

\section{Tradisi Gadai pada Masyarakat Gorontalo}

Provinsi Gorontalo terletak di bagian Utara pulau Sulawesi dan dihuni oleh etnis Gorontalo yang merupakan penduduk asli Gorontalo. Mayoritas penduduknya adalah Muslim. Masyarakat suku Gorontalo adalah masyarakat yang memiliki rasa sosial yang tinggi, sehingga hampir tidak pernah terjadi konflik di antara mereka sendiri. Sistem kekerabatan yang sangat erat tetap dipelihara oleh masyarakat Gorontalo, seperti dicontohkan dalam sistem ikatan keluarga pohala'a. ${ }^{11}$

Masyarakat pada dasarnya hidup dalam rangka memenuhi kebutuhannya guna mencapai kesejahteraan dan kemakmuran. Olehnya, setiap kelompok manusia saling berinteraksi melakukan kegiatan ekonomi baik di bidang jasa, perikanan, pertanian, perdagangan dan lain sebagainya. Setiap orang membutuhkan sesuatu dari orang lain, seperti tetangga maupun kerabatnya.

Transaksi pinjam-meminjam uang adalah salah satu alternatif pemenuhan hajat kehidupan di kalangan masyarakat. Sejak manusia mengenal uang sebagai alat pembayaran, pinjam meminjam uang telah ada, sebagai sesuatu yang sangat diperlukan untuk mendukung kegiatan ekonomi guna meningkatkan taraf hidup. Orang yang memiliki kelebihan harta memberikan bantuan pinjaman dana kepada orang yang memerlukannya.

Begitu pula yang terjadi pada masyarakat kabupaten Gorontalo, transaksi pinjam meminjam uang lazim terjadi. Khususnya bagi masyarakat petani biasanya dipersyaratkan adanya penyerahan jaminan utang oleh pihak peminjam kepada pihak pemberi pinjaman, yaitu agunan berupa lahan pertanian (sawah atau kebun). Dari hasil penelusuran di lapangan, dapat diketahui hal-hal prinsip yang harus terpenuhi ketika perjanjian gadai terjadi pada masyarakat berdasarkan hukum adat, gadai adat ini dalam tradisi masyarakat Gorontalo disebut dengan istilah pohulo'o. Pada masyarakat petani praktik gadai pohulo'o menjadi alternatif utama ketika seorang petani membutuhkan dana secara cepat, dikarenakan persyaratannya sederhana, ekonomis, dan tanpa proses administrasi yang berbelit-belit. Di samping itu perikatan dalam hukum adat telah dilakukan turun-temurun, berulang-ulang sehingga dirasakan mudah, bertitik tolak pada dasar kejiwaan, kekeluargaan serta tolong-menolong yang menjadi dasar hidup masyarakat Gorontalo yaitu budaya huyula.

Faktor utama terjadinya gadai pohulo'o adalah faktor ekonomi. ${ }^{12}$ Dalam hal ini pohulo'o merupakan akad ikutan atas akad utamanya yaitu peminjaman uang. Peminjaman dana berupa uang

\footnotetext{
9 Himan Hadi Kusuma, Hukum Perjanjian Adat (Bandung: Citra Aditya Bhakti, 1996).

10 Soejono Soekanto, Hukum Adat Indonesia (Jakarta: Raja Grafindo Persada, 2000).

11 Yaitu Ikatan Kekeluargaan yang erat.

12 Alex L. Talalu (39 tahun), Kepala Dusun Manggulipa Kec. Batudaa Kab. Gorontalo, dan Molki Amir (35), Petani/pekebun Desa Moahudu Kab. Gorontalo, Wawancara, Gorontalo, 14 Semptember 2020.
} 
tunai dilakukan untuk memenuhi kebutuhan dana hajatan atau musibah. Hajatan yang dimaksud bisa berupa perkawinan beserta rangkaian adat yang menyertainya hingga hari pelaksanaan akad dan resepsi pernikahan. Bisa juga hajatan berupa tradisi beat, yaitu prosesi adat bagi remaja putri Gorontalo ketika menanjak usia remaja, atau moluna yaitu prosesi adat khitan bagi laki-laki suku Gorontalo.

Musibah juga menjadi faktor utama terjadinya gadai pohulo'o. Musibah dapat dirinci berupa kematian atau sakitnya salah satu anggota keluarga. Penyelenggaraan jenazah dalam tradisi masyarakat Islam Gorontalo termasuk membutuhkan dana cukup besar ditambah dengan prosesi doa selama tujuh hari. Musibah berikutnya adalah sakitnya salah seorang keluarga inti di linkungan keluarga. Tidak seorangpun dapat menolak musibah, tidak jarang sakit yang diderita adalah penyakit parah yang membutuhkan pengobatan serius, pemeriksaan lab sampai dengan perawatan intensif di rumah sakit. Saat itu dibutuhkan biaya yang tidak sedikit, maka pinjaman uang dari pihak lain menjadi salah satu alternatif langkah yang diambil untuk memecahkan masalah.

Motivasi terjadinya gadai pohulo'o bisa juga disebabkan keinginan dari pemilik lahan untuk membeli lahan baru. Seorang petani ketika mengetahui ada lahan pertanian di tempat lain yang akan dijual maka dia akan mempertimbangkan ketersediaan dana yang dimilikinya. Biasanya ketika tabungan miliknya tidak mencukupi, maka lahan miliknya akan digadaikan kepada orang lain. Uang hasil meminjam dengan sistem pohulo'o ditambah dengan uang tabungannya digunakan untuk membeli lahan baru. Selanjutnya petani itu menggarap lahan barunya, dan hasil dari menggarap lahan baru tersebut secara bertahap dikumpulkan untuk melunasi pinjaman uang kepada pemegang gadai. Gadai pohulo'o juga dilakukan untuk memenuhi kebutuhan modal usaha, pembelian bibit dan pupuk tanaman, serta kebutuhan membeli hewan ternak. ${ }^{13}$ Kebutuhan dana pendidikan juga menjadi salah satu sebab terjadinya akad pohulo'o, terutama untuk membiayai perkuliahan anak pada semester akhir.

Akad gadai pohulo'o terjadi sebagaimana layaknya perjanjian pada umumnya. Seorang petani pemberi gadai mengadakan perjanjian utang kepada pihak lain sebagai penerima gadai. Atas kehendak pemberi gadai, objek gadai berupa lahan pertanian diserahkan kepada penerima gadai, penerima gadai dengan rela memberikan pinjaman sejumlah uang, selanjutnya penerima gadai menerima lahan objek pohulo'o untuk dikuasai selama beberapa waktu sesuai kesepakatan, atau selama utang belum terlunasi.

Saat ini akad pohulo'o selain dilakukan dengan ijjāb qabūl dengan perkataan, juga dilakukan pencacatan di atas kwitansi. Beberapa petani selain mencatatkannya di atas kwitansi, juga dilengkapi dengan surat pernyataan/penjelasan perjanjian akad pohulo'o. Di samping pencatatan di atas kwitansi, akad pohulo'o juga disertai saksi, yaitu kepala dusun, pihak keluarga dari 'pemberi' dan 'penerima' gadai, juga biasanya disaksikan oleh petani sekitar wilayah lahan pertanian yang menjadi objek jaminan gadai. ${ }^{14}$

Jika batas waktu penebusan objek pohulo'o habis dan pemberi gadai harus mengembalikan uang pinjaman tapi dia belum mampu mengembalikan uang tersebut, maka akan ada kesepakatan baru.

\footnotetext{
13 Yunus Karim (59 tahun), Petani dan Kepala Dusun Ilomangga Utara, Wawancara, Gorontalo, 14 Sepetember 2020.

14 Yasin Hasan (51 tahun), Sekretaris Kantor Desa Ilomangga Kec. Tabango Kab. Gorontalo, Wawancara, Gorontalo, 14 Sepetember 2020
} 
Dua hal kemungkinan bisa terjadi; pertama, perpanjangan waktu gadai, dan objek gadai tetap berada pada penerima gadai. Kedua, perpanjangan waktu gadai disertai penambahan jumlah pinjaman uang. Jika penambahan waktu gadai disertai dengan tambahan uang pinjaman, maka kesepakatan itu akan dinyatakan pada pencatatan yang baru di atas kwitansi. Pada beberapa kasus akad pohulo'o berahir dengan jual beli objek gadai. Pada kasus ini, objek gadai dibeli oleh penerima gadai, dengan cara penerima gadai menambahkan uang sejumlah harga yang disepakati oleh kedua belah pihak. Misalnya objek gadai dijual dengan harga Rp75.000.000 dan jumlah pinjaman uang yang telah diterima oleh pemberi gadai sejumlah Rp10.000.000, maka penerima gadai cukup memberikan uang kepada pemberi gadai uang sejumlah Rp65.000.000..$^{15}$

Pada akad pohulo'o selamanya yang menjadi objek gadai adalah barang tidak bergerak. Benda bergerak seperti motor, mobil, perhiasan emas dan lainnya tidak dijadikan objek gadai. Benda-benda bergerak biasanya dijadikan objek gadai oleh masyarakat Gorontalo pada lembaga pegadaian resmi. ${ }^{16}$

Setiap pohulo'o selalu dilakukan oleh orang dewasa, tidak pernah ada kejadian akad pohulo'o dilakukan oleh orang yang tidak cakap hukum. Pemberi gadai dan penerima gadai selamanya orang dewasa karena kesepakatan akad pohulo'o menyangkut persoalan tanggung jawab atas harta dalam jumlah besar. Ketika akad pohulo'o disepakati, maka penerima gadai memberikan sejumlah uang pinjaman kepada pemberi gadai yang dikuti penyerahan barang jaminan berupa lahan pertanian objek pohulo'o dari pemberi gadai kepada penerima gadai. Penerima gadai berkewajiban menjaga lahan ini dan berhak untuk mengelola lahan hingga waktu penebusan utang oleh pemberi gadai. Jika lahan objek pohulo'o sepenuhnya dikelola atau dikerjakan oleh penerima gadai, maka penerima gadai mengambil seluruh hasil panen. Tetapi jika pemberi gadai sebagai pengelola lahan maka pemberi gadai menerima dua bagian dari hasil panen, sementara penerima gadai mendapat satu bagian dari hasil panen. Pada mekanisme yang kedua ini, penerima gadai menerima bersih bagiannya dari hasil panen, penyediaan bibit, pupuk, kebutuhan obat semprot untuk hama dan lainnya terkait perawatan tanaman ditanggung oleh pemberi gadai. Selama dalam penguasaan penerima gadai, barang jaminan pohulo'o tidak bisa dijadikan barang gadai oleh penerima gadai apalagi menjualnya.

Pemberi gadai yang juga pemilik lahan berkewajiban membayar pajak atas kepemilikan lahan, meskipun lahan itu berada pada penguasaan penerima gadai. Pemberi gadai sepenuhnya masih memiliki hak atas lahan jaminan objek gadai pohulo'o, tetapi selama masa pohulo'o, pemberi gadai tidak berhak untuk menjualnya kepada orang lain. Jika pemberi gadai menjual lahan tersebut kepada orang lain maka harus atas persetujuan penerima gadai, yang disertai dengan pelunasan utang pinjaman setelah tranksaksi jual beli terjadi. ${ }^{17}$

Perjanjian gadai pohulo'o bersifat konsensuil. Kedua belah pihak bebas untuk mengambil bentuk apa saja dalam akad. Bisa jadi perjanjian itu dengan lisan saja, atau dengan lisan dan tulisan sekaligus. Akad pohulo'o yang tertulis bisa dilakukan di depan kepala lingkungan atau di kantor desa dengan kehadiran saksi dari pihak keluarga atau orang lain yang bukan keluarga. Saat ini akad pohulo'o hampir semua dilaksanakan dengan tercatat dan dilakukan dengan sepengetahuan kepala lingkungan atau kepala desa.

\footnotetext{
15 Rinto Karim (39 tahun), Sekretaris Kantor Desa Moahudu Kec. Tabango Kab. Gorontalo, Wawancara, Gorontalo 14 September 2020.

16 Abdul M. Jafar (50 tahun), Kepala Dusun Desa Tabongo Kab. Gorontalo, Wawancara, Gorontalo 16 September 2020

17 Yunus Kariim (59 tahun), Petani dan Kepala Dusun Ilomangga Utara, Wawancara, Gorontalo, 14 Sepetember 2020.
} 
Selama akad pohulo'o berlangsung pemegang gadai mempunyai beberapa hak yaitu:

1. Pemegang gadai berhak menahan barang gadai selama utang belum terlunasi.

2. Pemegang gadai berhak mengelola lahan gadai selama berada dalam kekuasaannya atau selama utang belum terlunasi.

3. Pemegang gadai berhak atas hasil panen lahan pohulo'o, juga berhak menetukan 'siapa' yang akan bekerja mengelola lahan tersebut. Bisa jadi yang bekerja adalah pemberi gadai atau bisa juga orang lain yang ditunjuk oleh pemegang gadai.

Jika pemegang gadai pada umumnya adalah kreditor separatis dengan mudah berhak menjual objek gadai (barang jaminan) ketika pemberi gadai wanprestasi, tidak demikian dengan gadai pohulo'o. Pemegang gadai tidak berhak menjual barang jaminan. Justru sebaliknya, pemegang gadai berhak untuk didahulukan 'membeli' barang gadai, jika pemberi gadai tidak mampu untuk menebusnya atau membayar utang.

Adapun pemberi gadai dalam akad pohulo'o memiliki hak:

1. Menerima uang gadai dari pemegang gadai

2. Menguasai kembali secara sempurna objek pohulo'o(barang jaminan) ketika utang terlunasi.

3. Memiliki keleluasaan memilih antara melunasi utang dan mengambil alih kembali objek pohulo'o, atau memperpanjang akad dengan tambahan uang dari penerima gadai atau tanpa tambahan uang.

Pada dasarnya akad pohulo'o dibatasi waktu, yang menjadi patokan adalah musim panen. Akad pohulo'o biasanya dilaksanakan dengan batas waktu 4 kali musim panen. Pemberi gadai tidak boleh menebus sewaktu-waktu lahan gadai sebelum masa panen tiba. Penebusan bisa dilakukan apabila pemegang gadai minimal telah melakukan satu kali masa panen.

Perjanjian gadai pohulo'o memiliki keleluasaan waktu tebus, karena waktu tebus sangat bergantung pada kesanggupan dan kemauan pemberi gadai sehingga tidak mengenal istilah waktu tebus yang kadaluarsa. Begitu pula penguasaan atas lahan oleh pemegang gadai menjadikannya tidak memiliki hak untuk menuntut penyegeraan dalam menebus lahan (gadai). Jika pemiliki lahan meninggal dunia hak untuk menebus beralih kepada ahli warisnya. Begitu pula jika pemegang gadai meninggal dunia, maka haknya jatuh kepada ahli warisnya.

Bagi pemberi pohulo'o yang debiturnya menginzinkannya untuk mengelola lahan atau menjadikannya sebagai penggarap, ia tetap bisa menikmati hasil panen dari lahannya. Ketentuan yang berlaku umum dalam akad pohulo'o, jika pemberi gadai sebagai pengelola lahan maka dia akan mendapatkan dua bagian dari hasil panen, sementara pemegang gadai mendapat satu bagian. Di satu sisi dana yang dibutuhkan dapat dia capai, di sisi lain lahan miliknya tetap berada dalam pengelolaannya, dia dapat menikmati hasilnya meskipun sebagian hasilnya harus diserahkan kepada pemegang gadai.

Lain halnya dengan pemberi gadai yang lahan pohulo'onya dikelola langsung oleh penerima gadai. Lahan tersebut tidak dapat lagi digarapnya dan secara otomatis tidak dapat lagi menikmati hasil tanaman dari lahan itu. Mekanisme pohulo'o seperti ini tidak menerapkan sistem bagi hasil yang menjadi kendala utama bagi pemberi gadai dalam meningkatkan kondisi ekonominya. Seandainya pemanfaatan lahan pohulo'o itu diberlakukan sistem bagi hasil sebagaimana mekanisme pertama, pihak penggadai juga dapat menikmati hasil tanah miliknya yang dijadikan sebagai jaminan maka 
pemberi gadai akan tetap terjaga kondisinya. Praktik seperti ini memberikan kesan tentang murtahin yang tidak adil karena bertindak konsumtif atas hasil panen, dan hanya mementingkan dirinya sendiri tanpa menaruh belas kasih kepada penggadai.

Pemanfaatan lahan jaminan oleh penerima gadai oleh masyarakat kabupaten Gorontalo lumrah terjadi. Faktor kebiasaan serta tradisi yang telah lama ada menjadikan praktik ini sah dan legal untuk dilakukan. Dalam pandangan mereka praktik ini sah terjadi, tidak bertentangan dengan prinsip keadilan maupun norma masyarakat. Baik pihak penggadai maupun penerima gadai sama-sama menjalani masa gadai dengan rido, suka rela, tanpa masalah, ataupun celaan dari orang lain. Secara riil dalam akad pohulo'o pemberi gadai memberikan izin kepada murtahin untuk memanfaatkan tanah jaminan. Pemanfaatan ini di satu sisi menjadikan tanah tersebut tetap produktif, tidak terbengkalai secara mubazir dan sia-sia, meskipun di satu sisi mengandung unsur eksploitasi.

\section{Analisis dan Resolusi Hukum Islam atas Tradisis Gadai Pohulo'o}

Tradisi pohulo'o adalah kearifan lokal yang tercipta dari hasil adaptasi masyarakat Gorontalo, berasal dari pengalaman hidup yang dikomunikasikan dari generasi ke generasi. Tradisi ini merupakan pengetahuan lokal yang digunakan oleh masyarakat Gorontalo untuk bertahan hidup pada lingkungan mereka masing-masing, menyatu dengan keyakinan, norma, budaya dan diekspresikan dalam pengamalan yang panjang. Peralihan hak atas tanah dalam gadai pohulo'o terjadi karena adanya perjanjian utang. Objek utama dalam akad pohulo'o adalah utang. Seorang petani pemilik tanah membutuhkan pinjaman uang dengan menjaminkan tanah miliknya atas utang tersebut. Utang menjadi suatu hal yang karenanya kesepakatan dibuat dan berlaku hukum-hukumnya. Objek akad berikutnya adalah jaminan benda. Dalam akad pohulo'o jaminan yang dimaksud adalah tanah yang merupakan benda tidak bergerak. Berbeda dengan ukum adat, benda jaminan gadai dalam KUH Perdata adalah benda bergerak. Dalam hukum Islam objek akad bisa saja benda bergerak atau benda tidak bergerak. ${ }^{18}$ Yang terpenting dalam ketentuan hukum Islam, objek akad (dalam hal ini utang dan jaminan) dapat diserahkan atau dilaksanakan. Objek akad yang tidak dapat direalisasikan dalam hukum Islam disebut garar. Akad yang di dalamnya mengandung unsur garar, dilarang dalam Islam:

$$
\text { عن أبى هريرة قال نهى رسول الله صلى الله عليه و سلم عن بيع الحصاة و عن بيع الغرر }
$$

Dari Abu Hurairah ia berkata: Rasulullah saw. melarang jual beli lempar kerikil dan jual beli garar. ${ }^{19}$

Hal penting lainnya dari barang agunan, bahwa barang tersebut bernilai dan dapat dijual. Apabila debitur tidak melunasi utangnya, hasil penjualan agunan dapat diambil sebagai biaya pelunasan utang.

Objek akad berupa "utang” menurut hukum Islam selain mampu diadakan oleh penerima gadai, juga harus dikembalikan oleh pemberi gadai. Nilai utang dapat terlunasi dengan agunan, artinya harga barang gadai dengan jumlah utang nilainya seimbang atau lebih, jangan sampai nilai utang lebih besar dari nilai agunan. Di samping dua syarat itu utang harus jelas jumlahnya dan secara spesifik

\footnotetext{
18 UripSantoso, Hukum Agraria Kajian Komprehensif (Jakarta: PRENADAMEDIA GROUP, 2012).

${ }^{19}$ Abū al-Ḥusayn ‘Asākir al-Dīn Muslim ibn al-Ḥajjāj ibn Muslim al Qushayrī al Naysābūrī, Șaḥịh Muslim Juz. II (Beirut: Dār al-Fikr, 1992).
} 
dapat ditentukan. Hak yang berkaitan dengan benda gadai dalam akad pohulo'o bersifat memberi jaminan dan memberi kenikmatan sekaligus. Fungsi tanah agunan dalam tradisi ini adalah jaminan sekaligus sumber pendapatan baru bagi penerima gadai. Hak ini berbeda denga hak gadai yang diatur dalam fikih rahn dan KUH Perdata. Menurut pasal 25 UUPA, hak milik atas tanah dapat dijadikan jaminan utang dengan dibebani dengan hak tanggungan. Syarat sah terjadinya Hak Tanggungan harus memenuhi tiga unsur yang bersifat kumulatif, yaitu; pertama, adanya utang piutang sebagai perjanjian pokoknya. Kedua, adanya akta pemberian hak tanggungan sebagai perjanjian ikutan tambahan. Adanya penyerahan hak milik atas tanah sebagai jaminan utang dari debitur kepada kreditur, harus dibuktikan dengan Akta Pemberian Hak Tanggungan oleh Pejabat berwenang. Ketiga, adanya pendaftaran Akta Pemberian Hak Tanggungan. Akta pemberian hak tanggungan yang dibuat wajib didaftarkan kepada Kantor Pertanahan setempat untuk dicatat dalam Buku Tanah dan diterbitkan sertipikat Hak Tanggungan. ${ }^{20}$

Minimnya pengetahuan masyarakat kabupaten Gorontalo tentang UUPA dan peraturan pemerintah tentang pertanahan mengakibatkan hamper semua tanah pertanian yang dijadikan jaminan tidak didaftarkan secara administrasi hukum yang berlaku. Disamping itu masyarakat petani tidak terbiasa dengan urusan administrasi yang menyangkut surat-surat resmi, tulis-menulis dan tahap urutan prosedur yang dilalui, begitu pula mereka enggan mengeluarkan uang untuk biaya pendaftaran dan biaya pengurusan. Bagi mereka tahapan itu menyusahkan, dan tidak semua dari mereka memiliki surat-surat resmi yang disyaratkan. Pada umumnya masyarakat tidak bisa membedakan antara fungsi tanah yang manfaatnya untuk dinikmati dan fungsi tanah hanya sebatas jaminan.

Jika ditinjau dari unsur-unsur penyusun akad, gadai pohulo'o dapat memenuhi unsur-unsur penyusun akad. Yang menjadi masalah utama adalah pemanfatan tanah (marhūn) sebagai jaminan gadai oleh murtahin. Pada asalnya barang gadai dan manfaatnya adalah milik orangyang menggadaikan (rāhin). Murtahin bisa memanfaatkan marhūn sekedarnya untuk menutupi biaya pemeliharaan marhūn yang ada di tangannya. Jumhur Ulama fikih selain mazhab Hanbali berpendapat bahwa pemegang agunan tidak boleh memanfaatkan barang agunan tersebut, karena barang itu bukan miliknya secara penuh. Hak pemegang agunan hanya sekedar jaminan piutang yang ia berikan. Akan tetapi apabila pemilik agunan mengizinkan pemegang agunan memanfaatkan barang tersebut selama di tangannya, maka sebagian Ulama Mazhab Hanafi membolehkannya, karena dengan adanya izin tersebut maka tidak ada halangan bagi pemegang agunan untuk memanfaatkan barang itu. Pemanfaatan tanah dalam gadai pohulo'o oleh pemegang gadai secara konkret diizinkan oleh rāhin. Jika demikian adanya, hukum adat yang berlaku dalam gadai pohulo'o masih dapat dikompromikan dengan ketentuan rahn dalam hukum Islam.

Pohulo'o telah menjadi salah satu cara hidup masyarakat Gorontalo di bidang ekonomi yang dipraktikkan secara turun-temurun. Prinsip Islam membiarkan kearifan lokal dan kebudayaan lokal yang produktif dan tidak mengotori akidah untuk tetap eksis. Jika memang terjadi perbedaan yang mendasar maka Islam biasanya merekonstruksi kembali budaya itu. Nilai-nilai Islam di bidang akidah tidak dapat ditawar-tawar, tetapi di bidang muamalat sebagai tuntunan norma hubungan sesama manusia, Islam mengambil sikap terbuka. Misalnya perihal jual beli yang pada prinsipnya tidak boleh yaitu jual beli salaf (pesan) dan menjual sesuatu yang tidak ada padanya. Secara tegas Nabi Saw melarang praktik ini:

${ }^{20}$ Maria S.W. Sumardjono, Tanah Dalam Perspektif Hak Ekonomi Sosial Dan Budaya (Jakarta: PT Kompas Media Nusantara, 2008). 


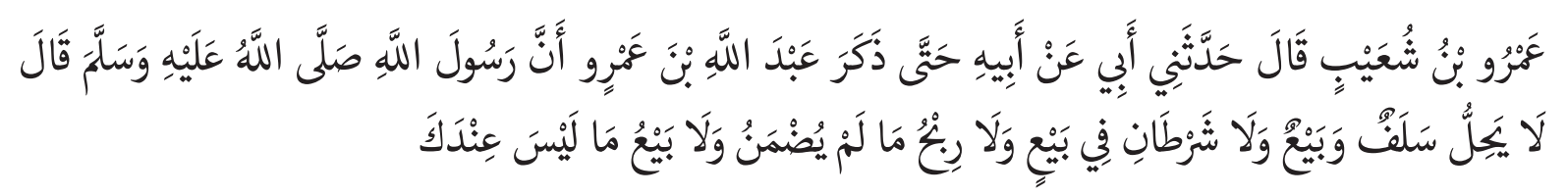

Amru bin Syu'aib ia berkata; telah menceritakan kepadaku ayahku dari ayahnya hingga ia menyebut Abdullah bin Amru bahwa Rasulullah shallallahu 'alaihi wasallam bersabda: “Tidak halal mencampurkan jual beli salaf, tidak pula dua syarat dalam satu jual beli dan tidak halal laba terhadap barang yang tidak dapat dijamin (baik dan buruknya), serta tidak halal menjual apa yang tidak kamu miliki."

Namun, ada pengecualian dari hadis ini karena kemaslahatan yang lebih urgen, yakni pemenuhan kebutuhan manusia, sehingga akad jual beli dengan sistem pesan, dan jual beli yang barangnya belum ada sah dilakukan. Metode istinbāț hukum seperti ini di kalangan Hanafiyah disebut dengan istiḥsān, yaitu meninggalkan qiyas dan mengamalkan yang lebih kuat dari itu karena dalil yang menghendaki demikian, serta lebih sesuai dengan kemaslahatan umat manusia. ${ }^{21}$

Ketika Rasulullah saw. hijrah ke Madinah, beliau mendapatkan tradisi jual beli yang juga bertentangan dengan hadis yang telah disebutkan sebelumnya. Mereka masyarakat petani yang ada di Madinah melakukan jual beli buah yang belum dipanen, yaitu buah kurma yang masih di pohon. Apa yang dilakukan masyarakat Madinah bertentangan dengan ketentuan hukum Islam tentang jual beli barang yang belum ada, atau belum jelas akan ada di kemudian hari. ${ }^{22}$ Tetapi kemudian Rasulullah mengizinkan tradisi jual beli masyarakat Madinah ini dengan memberikan syarat dan ketentuan yang harus dipatuhi. ${ }^{23}$

Baik Islam maupun budaya dan norma adat, secara umum memiliki fungsi yang serupa, yakni untuk memanusiakan manusia dan membangun masyarakat yang beradab dan berperikemanusiaan. Islam mempunyai karakter dinamis, elastis dan akomodatif dengan budaya lokal selama tidak bertentangan dengan prinsip-prinsip Islam itu sendiri. Permasalahannya terletak pada tata cara dan teknis pelaksanaan. Gadai pohulo'o secara teknis dapat dibagi dua. Teknis pertama yaitu lahan marhūn dikerjakan sendiri oleh pemegang barang gadai tanpa melibatkan pemilik lahan (rāhin). Teknis kedua, pemilik lahan dijadikan mitra kerja oleh pemegang gadai dengan sistem bagi hasil. Untuk gadai pohulo'o dengan teknis pertama nampak dengan jelas apa yang semestinya dihindari dalam hukum muamalah Islam. Meskipun niat awal murtahin adalah mengeluarkan rāhin dari masalah hidupnya melalui pinjaman uang, tetapi konsekuensi penguasaan lahan milik petani sangat memberatkan untuknya dan menyebabkan sumber penghidupannya hilang. Hal ini tentu saja bertentangan dengan nilai-nilai muamalah dalam Islam. Namun untuk teknis kedua gadai pohulo'o yaitu melibatkan rāhin sebagai pemilik lahan dalam mengerjakan lahan pohulo'o dengan sistem bagi hasil antara rāhin dan murtahin, dalam hal ini manfaat hasil panen tidak dinikmati sendiri oleh murtahin tetapi juga dinikmati oleh rāhin. Rāhin dapat keluar dari masalah keuangannya dan sumber penghasilannya tetap ada demi menutupi kebutuhannya sehari-hari.

Islam memandang tradisi dan adat yang ada di masyarakat sebagai hal yang memiliki kekuatan hukum. Teori ini diambil dari adanya realitas sosial kemasyarakatan bahwa semua cara hidup dan kehidupan itu dibentuk oleh nilai-nilai yang diyakini sebagai norma kehidupan, sedang setiap individu

\footnotetext{
${ }^{21}$ Muhammad Abū Zahrah, Abū Hanīfah Hayātuh Wa 'Așruh Wa Fiqhuh (Beirut: Dār al-Fikr al-'Arabī, 1990).

22 Yūsuf al- Qaraḍāwī, Al-Sunnah Mașdaran Li Al-Ma'rifah Wa Al-Haḍarah (Kairo: Dār al-Syurūq, 1998).

23 Abū al-Ḥusayn ‘Asākir al-Dīn Muslim ibn al-Ḥajjāj ibn Muslim al Qushayrī al Naysābūrī, Șaḥịh Muslim Juz. II.
} 
dalam bermasyarakat dalam melakukan sesuatu itu karena sesuatu tersebut dianggap bernilai, sehingga dalam komunitas mereka memiliki pola hidup dan kehidupan mereka sendiri secara khusus berdasarkan nilai-nilai yang sudah dihayati bersama. Gadai adat sebagai suatu praktik muamalah tetap hidup dan dipraktikkan di masyarakat di berbagai daerah, termasuk daerah Gorontalo. Kesederhanaan dalam pola transaksi, tidak berbelit-belit, dan tidak membutuhkan kelengkapan administrasi yang menyusahkan melekat sebagai nilai-nilai pohulo'o yang menurut masyarakat menjadi norma yang mudah dijalankan bersama. Dipraktikkannya pohulo'o secara turun temurun menjadi fakta yang harus dipandang sebagai hukum yang hidup di tengah-tengah mereka. Artinya gadai pohulo'o adalah representasi hukum yang otentik bagi masyarakat Gorontalo. Proses kreatifitas dan imajinatif dalam membangun nilai-nilai atau norma-norma budaya yang terus dipraktikkan secara kolektif oleh sebuah komunitas masyarakat, dalam hukum Islam disebut dengan 'urf.

Berbeda dengan mayoritas Ulama lainnya, jumhūr Ulama Hanafiyah berpendapat bahwa murtahin boleh memanfaatkan barang gadai apabila ada izin dari rāhin. Mereka mempersyaratkan bahwa izin pemanfaatan barang gadai tersebut tidak bisa dipersyaratkan di akad. Menurut mereka izin pemanfaatan marhūn oleh murtahin adalah bentuk tabarru' dari rāhin kepada murtahin.

Jika diuraikan beberapa fakta yang berhubungan dengan tradisi pohulo'o yaitu:

1. Pohulo'o dilakukan untuk mengatasi kebutuhan hidup individu dibidang ekonomi.

Kecendrungan manusia adalah memenuhi kebutuhannya. Pemenuhan akan kebutuhan biasanya tidak dapat ditunda, harus segera dipenuhi. Karena jika tidak terpenuhi, akan berpengaruh terhadap keberlangsungan hidup atau bisa menimbulkan dampak negativ. Kebutuhan seseorang sangat beragam dan bisa datang secara tiba-tiba, kadang-kadang tanpa disertai kemampuan untuk membeli barang atau membayar jasa yang dibutuhkan.

2. Motivasi utama akad Pohulo'o adalah tolong menolong.

Hasil penelusuran di lapangan memberikan kesimpulan bahwa murtahin sebagai kreditor adalah pihak yang pasif. Kebutuhan rāhin yang harus segera dipenuhi, memaksanya sengaja mendatangi murtahin untuk meminta pertolongan meminjam uang. Tidak ditemukan kasus murtahin dengan segaja mencari-cari calon debitur yang dalam keadaan susah untuk dipinjamkan uang kemudian dieksploitasi tanahnya oleh murtahin. Pemberi gadai dengan leluasa dapat meneruskan atau membatalkan akad, begitu pula dia leluasa memilih siapa yang akan menjadi murtahin.

3. Pohulo'o adalah tradisi gadai dengan mekanisme khusus, dimana debitur memiliki waktu luas dalam pembayaran.

Sebagai bentuk interaksi antar individu masyarakat di bidang muamalah yang lahir dari budaya, gadai pohulo'o memiliki mekanisme khusus dimana utang yang didapatkan dari gadai pohulo'o tidak akan kadaluwarsa. Barang gadai dalam akad pohulo'o tidak bisa dijual oleh murtahin. Murtahin setelah menerima marhūn memiliki hak untuk memanfaatkannya. Hak pemanfaatan marhūn dalam hal ini berbanding lurus dengan hak rāhin untuk menunda pembayaran utangnya.

4. Tidak susah dan berbelit-belit dalam hal formalitas akad.

Berbeda dengan akad gadai pada lembaga keuangan resmi, akad pohulo'o dilakukan dengan cara sederhana. Penggadai cukup mencari murtahin yang siap meminjamkan uang 
kepadanya, setelah terjadi kesepakatan murtahin menyerahkan uang (piutang) kepada rāhin, kemudian murtahin menerima lahan pohulo'o. Akad dicatat di atas kwitansi dan dilakukan di depan kepala dusun atau kepala lingkungan. Kesepakatan terjadi tanpa mempersyaratkan berbagai prosedur administrasi resmi. Yang terpenting bagi masyarakat Gorontalo bahwa perjanjian tersebut didasarkan pada kesepakatan bulat dari rāhin dan murtahin.

5. Lahan pertanian objek gadai dimanfaatkan.

Pengelolaan tanah secara bijaksana adalah sebuah keniscayaan saat ini, mengingat tanah dalam skala hamparan merupakan sumber daya pertanian yang menghasilakan bahan pangan. Indonesia umumnya akan terus dihadapkan pada problem pemenuhan kebutuhan pangan bagi rakyat karena populasi manusia terus berkembang termasuk di dalamnya daerah Gorontalo.

Islam memberikan penghargaan besar atas pengelolaan tanah dan pemanfaatannya yang berperan dalam penyediaan pangan bagi manusia dan mahluk hidup lainnya. Dalam sebuah hadis Rasulullah saw. bersabda:

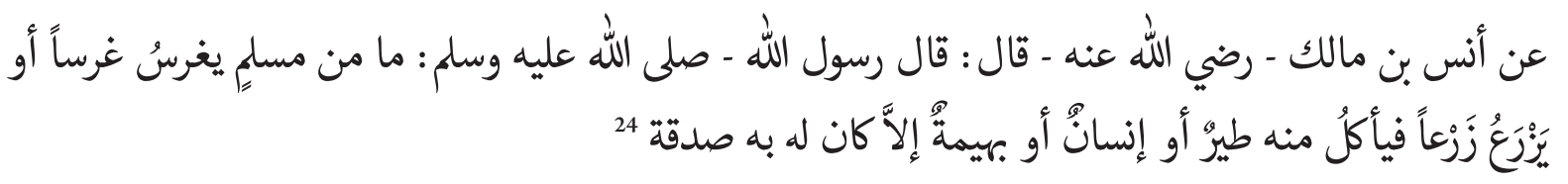

Dari Anas bin Mālik ra. ia berkata: Rasulullah saw. bersabda: Tak seorangpun muslim yang menanam pohon atau tanaman, lalu dimakan oleh burung, manusia, atau hewan lainnya, kecuali akan menjadi sedekah baginya (HR. Al Bukhārī).

Islam menganjurkan pemanfaatan tanah untuk penyediaan pangan sebagai suatu kewajiabn utama tugas kekhalifahan manusia di bumi. Etika Islam juga mengajarkan manusia untuk menghidupkan lahan mati untuk dijadikan lahan yang lebih produktif.

Tradisi pohulo'o merupakan bagian dari 'urffi'ti. Dalam praktiknya dibagi dalam dua mekanisme. Mekanisme pertama, tanah pohulo'o digarap oleh murtahin tanpa melibatkan rāhin. Dalam hal ini semua hasil panen diambil oleh murtahin. Mekanisme kedua, tanah marhūn dikelola oleh murtahin dengan melibatkan rähin sebagai pekerja/pengelola lahan. Hasil panen dibagi tiga, satu bagian untuk murtahin dan dua bagian untuk rāhin sebagai pekerja. Hukum Islam mengandung prinsip bahwa manusia bebas melakukan berbagai akad. Yaitu suatu prinsip hukum yang menyatakan bahwa setiap orang dapat membuat akad jenis apapun tanpa terikat kepada nama-nama yang telah ditentukan dalam undang-undang syariah. Begitu pula setiap orang bebas memasukkan klausal apa saja ke dalam akad yang dibuatnya itu sesuai dengan kepentingan akad itu dibuat. Terciptanya suatu akad dalam hukum Islam cukup dengan tercapainya kata sepakat antara para pihak yang berakad tanpa perlu formalitas-formalitas tertentu, semua akad dalam hukum Islam bersifat konsensualisme.

Melalui gadai pohulo'o diharapkan penggadai dapat memenuhi kebutuhannya sehingga dapat diperoleh kehidupan yang baik (hayātan țayyiban). Pada mekanisme akad pohulo'o tanpa melibatkan penggadai sebagai penggarap lahan didapatkan fakta bahwa kehidupan yang baik itu akan sangat sulit dicapai oleh penggadai setelah terjadinya akad. Hal ini dikarenakan penggadai akan hilang sumber pendapatannya. Penghasilan ekonomi yang diperoleh hanya menguntungkan pihak murtahin dan

${ }^{24}$ Abū ‘Abd Allāh Muhammad ibn Ismā‘īl ibn Ibrāhīm ibn al Mugīrah al Bukhārī, Șahịị al Bukhārī Juz. I No. Haidis 2320 (Kairo: Dār Al Hadïs, t.th), h. 226 
merugikan pihak rāhin. Sementara dalam hukum Islam, penghasilan yang diperoleh bertujuan demi tercapainya falāh bagi pihak-pihak yang bertransaksi. Islam juga mengharuskan adanya distribusi pendapatan dan kekayaan yang adil dengan memberikan nilai yang sangat penting bagi persaudaraan dan keadilan sosial ekonomi.

Distribusi penghasilan secara merata pada gadai pohulo'o dengan mekanisme ini tidak terjadi. Yang terjadi adalah kesenjangan penghasilan antara penggadai dan pemegang gadai, pemegang gadai terus mendapatkan hasil panen dan menikmatinya sedangkan penggadai harus berjuang untuk mendapatkan sumber penghasilan lain demi menutupi kehidupannya beserta keluarga. Jika penggadai memiliki beberapa lahan selain lahan yang telah dijaminkannya, maka dengan memaksimalkan sisa lahan yang dimiliki, dia tidak akan merasa terlalu susah, akan tetapi jika satusatunya lahan yang dimiliki yang telah menjadi pohulo'o, hal ini tentu saja akan mengakibatkan kesengsaraan bagi hidupnya.

Kebutuhan petani penggadai yang tidak dapat dihindari mengharuskannya menjadi seorang debitur. Uang pinjaman membantunya keluar dari masalah, tetapi ketika lahan yang dijaminkannya tidak dapat lagi digarap maka yang terjadi adalah ketimpangan ekonomi pada hidupnya. Inilah yang dikhawatirkan oleh para Ulama tentang terjadinya eksploitasi murtahin atas rāhin. Olehnya mekanisme pohulo'o dengan skema lahan jaminan dikerjakan sepenuhnya oleh murtahin harus dihindari.

Akan tetapi yang harus dipertegas pula pada tradisi pohulo'o, bahwa penggadai pada situasi yang mengharuskannya untuk mendapatkan pinjaman dari seorang kreditur untuk memenuhi kebutuhannya, baik itu kebutuhan primer alamiah atau kebutuhan sekunder. Seorang Kreditur pada gadai pohulo'o masyarakat Gorontalo niat utamanya adalah membantu rāhin memberikan pinjaman uang, sehingga dugaan eksploitasi murtahin atas rāhin dapat disepelekan, dalam arti tidak ada paksaan sama sekali dari murtahin untuk menggadaikan tanah milik rāhin. Rāhin dengan leluasa bisa membatalkan perjanjian pohulo'o pada waktu akad, atau juga dia leluasa memilih murtahin mana yang akan menjadi rekanan transaksinya.

Menurut peneliti yang terjadi pada akad pohulo'o dengan mekanisme rāhin sebagai penggarap adalah akad untuk melakukan penjaminan (al-tawsīq) juga sekaligus akad untuk melakukan persekutuan (al isytirāk). Posisi dimana murtahin memberikan sejumlah pinjaman uang kepada rāhin, kemudian rāhin memberikan tanah miliknya sebagai jaminan, merupakan akibat hukum yang ditimbulkan oleh akad pohulo'o. Selanjutnya untuk merealisasikan akibat hukum pohulo'o tersebut maka pihak rāhin dan murtahin memikul beberapa kewajiban. Kewajiban rāhin menjadi hak murtahin dan hak rāhin menjadi kewajiban murtahin. Pihak rāhin 'berkewajiban' untuk menyerahkan tanahnya untuk menjadi jaminan utang (tawsī $)$ ), di lain pihak rāhin juga memiliki 'hak' untuk disertakan (al-isytiräk) dalam pengelolaan lahan jaminan tersebut selama lahan tersebut menjadi jaminan utang. Selama utang belum terbayar maka lahan masih tetap menjadi pohulo'o dan murtahin tetap mendapatkan bagiannya dari hasil panen. Di lain pihak rāhin memiliki waktu leluasa untuk membayar utangnya. Utang tersebut bukan tidak akan dibayar, akan tetapi ketika keadaannya telah leluasa maka rāhin pasti akan membayar utang tersebut.

Akad pohulo'o dengan mekanisme ini tercipta melalui budaya huyula yang merupakan kearifan lokal masyarakat Gorontalo. Secara jelas kemaslahatan yang ingin dicapai oleh hukum Islam bisa direalisasikan melalui pemenuhan hak dan kewajiban masing-masing dari pihak rāhin dan murtahin. Syariat sebagaimana mengutamakan kemaslahatan-kemaslahatan yang pokok, 
juga sangat mengutamakan kaidah hạjiyāt yang bertujuan memberikan kelapangan dan menolak kesukaran dalam menanggulangi berbagai masalah hukum, dengan pertimbangan apabila masalah hājiyāt ini tidak ditolerir maka akan timbul sejumlah kesulitan dan kesukaran dalam melaksanakan kemaslahatan pokok. Dalam kasus gadai pohulo'o kemaslahatan rāhin untuk keluar dari permasalahan hidupnya harus terjaga dan terselesaikan. Pemanfaatan barang pohulo'o menurut mayoritas Ulama tidak dibolehkan, akan tetapi jika ini diterapkan akan menimbulkan kesusahan. Maka dalam hal ini gadai pohulo'o tidak dapat diqiyāskan dengan rạ̣n, karena jika terjadi qiyās maka kemaslahatan yang menjadi tujuan hukum Islam tidak akan tercapai.

\section{Penutup}

Masyarakat dengan tradisi hidup mereka adalah dua hal yang susah dipisahkan. Tradisi telah menyediakan sarana dan alat kehidupan demi keberlangsungan hidup manusia dari generasi ke generasi. Ketika tradisi tersebut meyangkut hajat hidup maka akan semakin susah tradisi tersebut dipisahkan dari masyarakat yang mempraktikkannya, apalagi jika tradisi tersebut telah menyediakan kemudahan. Gadai yang dijalankan secara hukum adat adalah sarana bagi masyarakat menengah ke bawah untuk menanggulangi kebutuhan akan uang. Khususnya masyarakat petani, pada umumnya mereka tidak mampu memenuhi persyaratan administrasi untuk peminjaman uang pada lembaga keuangan resmi, maka gadai adat merupakan kompensasi yang manjur.

Berdasarkan fakta inilah hukum Islam khususnya mujtahid harus mampu melihat realitas masyarakat untuk kemudian memadukannya dengan metodologi dan dalil-dalil syar'iy. Islam adalah agama yang mengakui eksistensi akan adanya norma dan nilai-nilai yang dipraktikkan dan disepakati bersama oleh masyarakat. Jika nilai dan norma tersebut bertentangan dengan syari'at, maka Islam dapat membatalakan sebagian dari norma itu dan merekonstruksi bagian yang lainnya. Gadai yang dijalankan secara adat adalah bagian dari tradisi masyarakat yang harus direkonstruksi kembali oleh hukum Islam agar berkesesuaian dengannya, sebab karakter hukum Islam di bidang muamalah bersikap terbuka.

\section{Daftar Pustaka}

'Abd Al-Raḥmān Al Jazīrī. Al-Fiqh 'alā Mażāhib Al'Arba'Ah. Mesir: Al-Maktabah al-Tijāriyah, 1998.

Abū al-Ḥusayn 'Asākir al-Dīn Muslim ibn al-Ḥajāj ibn Muslim al Qushayrī al Naysābūrī. Șaḥịh Muslim Juz. II. Beirut: Dār al-Fikr, 1992.

Abū Ishāq al Syāțibī. Al-Muwāfaqāt Fi Usūl Al-Syari’ah. Beirut: Dār al Ma'rifah, n.d.

Hartono Hadisoeprapto. Pengantar Tata Hukum Indonesia. Yogyakarta: Liberty, 2000.

J. Satrio. Hukum Jaminan Hak Jaminan Kebendaan. Bandung: PT. Citra Aditya, 2002.

Kusuma, Himan Hadi. Hukum Perjanjian Adat. Bandung: Citra Aditya Bhakti, 1996.

Maria S.W. Sumardjono. Tanah Dalam Perspektif Hak Ekonomi Sosial Dan Budaya. Jakarta: PT Kompas Media Nusantara, 2008.

Muhạmmad Abū Zahrah. Abū Ḥanīfah Ḥayātuh Wa 'Așruh Wa Fiqhuh. Beirut: Dār al-Fikr al-'Arabī, 1990. Ronald Saija. Buku Ajar Hukum Perdata. Yogyakarta: Deepublish, 2016. 
Sābiq, Sayyid. Fiqh Al-Sunnah. Cairo: Dār al-Fatḥ, 1997.

Soekanto, Soejono. Hukum Adat Indonesia. Jakarta: Raja Grafindo Persada, 2000.

Subekti. Pokok-Pokok Hukum Perdata. Jakarta: Intermasa, 1999.

UripSantoso. Hukum Agraria Kajian Komprehensif. Jakarta: PRENADAMEDIA GROUP, 2012.

Wahbah Al-Zuhailī. Al-Fiqh Al-Islāmī Wa Adillatuh Juz V. Libanon: Dār al-Fikr, 1998.

Yūsuf al- Qaraḍ̄āī. Al-Sunnah Maṣdaran Li Al-Ma'rifah Wa Al-Hậ̄ārah. Kairo: Dār al-Syurūq, 1998.

al-Bukhārī, Abū 'Abd Allāh Muḥammad ibn Ismā‘̄il ibn Ibrāhīm ibn al Mugīrah , Șahịḥ al Bukhārī Juz. I No. Haidis 2320 (Kairo: Dār Al Hadīs, t.th), h. 226 